\title{
Effect of glycerin on digestibility of diets for pigs determined with different methodologies
}

\section{Efeito da glicerina sobre a digestibilidade de dietas para suínos determinado com diferentes metodologias}

\author{
Guiomar Helena Verussa ${ }^{1}$; Anderson Corassa ${ }^{2 *}$; Ana Paula Silva Ton ${ }^{2}$; Cláudia \\ Marie Komiyama²; Douglas dos Santos Pina²; Alexandre de Oliveira Teixeira ${ }^{3}$; \\ Leonardo Marmo Moreira ${ }^{3}$; Charles Kiefer ${ }^{4}$
}

\begin{abstract}
Glycerin is a by-product from the biodiesel chain whose energy value can be beneficial to pig diets. In this study, eight barrows were distributed individually into metabolic cages in a completely randomized block design. The animals were fed diets containing $0,5,10$ and $15 \%$ glycerin from soybean oil and subjected to the methods of total feces and urine collection and chromic oxide marker. We determined the digestibility coefficients (DC); the dietary levels of digestible dry matter (DM), organic matter $(\mathrm{OM})$, crude protein $(\mathrm{CP})$, mineral matter $(\mathrm{MM})$, ether extract (EE), an neutral detergent fiber (NDF); digestible energy (DE); metabolizable energy (ME); and these last two variables corrected for the nitrogen content (DEn and MEn). Digestible OM values increased linearly with glycerin inclusion in the diets. The digestible $\mathrm{CP}$ of the diets showed an inversely proportional relationship with glycerin inclusion levels. Digestible MM decreased linearly when determined by the total collection method and quadratically when determined by the marker method. There was a linear increase in the digestible and metabolizable coefficients of energy, DE, DEn, ME and MEn of the diets as the glycerin inclusion level was increased. Inclusion of up to $15 \%$ glycerin obtained from soybean oil production increased the digestible fractions of organic matter and energy of the diets.
\end{abstract}

Key words: Biodiesel. Digestibility. Glycerol. Marker. Metabolizability. Total feces collection.

\section{Resumo}

A glicerina é um coproduto oriundo da cadeia do biodiesel que possui valor energético capaz de contribuir favoravelmente em dietas para suínos. Neste estudo, foram utilizados oito suínos machos castrados, distribuídos individualmente em gaiolas de metabolismo em delineamento experimental de blocos ao acaso. Os animais foram alimentados com dietas contendo 0,5,10 e 15\% de glicerina oriunda do óleo de soja, submetidos ao método de coleta total de fezes e urina e o indicador óxido crômico. Foram determinados os coeficientes de digestibilidade (CD); e níveis dietéticos digestíveis de matéria seca $(\mathrm{MS})$, matéria orgânica $(\mathrm{MO})$, proteína bruta $(\mathrm{PB})$, matéria mineral $(\mathrm{MM})$, extrato etéreo $(\mathrm{EE})$ e

1 M.e em Zootecnia. Programa de Pós-Graduação em Zootecnia, Universidade Federal de Mato Grosso, UFMT, Campus Universitário de Sinop, Sinop, MT, Brasil. E-mail: guiomarhverussa@gmail.com

2 Profs. Drs., Programa de Pós-Graduação em Zootecnia, UFMT, Campus Universitário de Sinop, Sinop, MT, Brasil. E-mail: anderson_corassa@ufmt.br; anatonn4@hotmail.com; claudiamarie@ufmt.br; douglaspinaufmt@gmail.com

3 Profs. Drs., Universidade Federal de São João Del Rei, UFSJD, Departamento de Zootecnia, São João Del-Rei, MG, Brasil. E-mail: alexandre teixeira@ufsj.edu.br; leonardomarmo@gmail.com

4 Prof. Dr., Programa de Pós-Graduação em Ciência Animal, Universidade Federal de Mato Grosso do Sul, UFMS, Departamento de Zootecnia, Campo Grande, MS, Brasil. E-mail: charles.kiefer@ufms.br

* Author for correspondence 
fibra em detergente neutro (FDN); energia digestível (ED), energia metabolizável (EM) e correção pelo teor de nitrogênio (EDn, EMn) das dietas. Os valores de MO digestível aumentaram de forma linear com a inclusão de glicerina nas dietas. Os valores de PB digestível das dietas tiveram uma relação inversamente proporcional aos níveis de inclusão de glicerina. $\mathrm{O}$ valor de MM digestível diminuiu de forma linear, quando determinado pelo método de coleta total, e de forma quadrática, quando determinado pelo método de indicador. Houve aumento linear nos coeficientes de digestibilidade e metabolizabilidade da energia, ED, EDn, EM e EMn, das dietas em função do aumento de inclusão de glicerina. A inclusão de até 15\% de glicerina obtida do óleo de soja aumentou as frações digestíveis de MO e energia das dietas.

Palavras-chave: Biodiesel. Digestibilidade. Glicerol. Marcador. Metabolizabilidade. Coleta total de fezes.

\section{Introduction}

Brazil has approximately $44 \%$ of its energy matrix originating from renewable sources, having produced almost 3,500,000 $\mathrm{m}^{3}$ of biodiesel in 2016 (ANP, 2017). This production has generated an increase in the amount of by-products resulting from from this chemical process, including glycerin, which has fostered research investigations on useful applications of the biodiesel surplus production. In this context, glycerin appears to be the only byproduct associated with the biodiesel production chain whose energy value can favorably contribute to diets for pigs.

In addition to its high level of metabolizable energy (around 3,579 $\mathrm{kcal} / \mathrm{kg}$ ), which is similar to that of corn (around 3,340 kcal $/ \mathrm{kg}$ ) (ROSTAGNO et al., 2011), glycerin is considered palatable to animals, as it is a sweet liquid, and can be used by pigs as glycogenic or lipogenic source (JAGGER, 2008). However, its nutritional value and influence on pig diets may vary according to several factors; e.g., type of feedstock employed in the biodiesel production, chemical characterization, evaluation method used in the process, inclusion level of the test feed, statistical analysis, among others.

The raw material profile used in biodiesel production in Brazil has the soybean oil as the main source, corresponding to approximately $69 \%$ (ANP, 2017). As stated by Oliveira et al. (2013), considering the total biodiesel produced in the plants, $33.2 \%$ were generated in those using soybean oil exclusively; $36.8 \%$ in plants that employ soybean and tallow; and $9.1 \%$ in units that use the soybean and cottonseed oils.

There is not a consensus regarding the adequate level of glycerin inclusion in pig feeding in the different animal production phases; e.g., 12-14\% for 15 to $30 \mathrm{~kg}$ (DROSGHIC et al., 2013) and 15\% for 97 to $115 \mathrm{~kg}$ (LEITE et al., 2017). Still, studies analyzing the effect of glycerin addition to pig diets can be considered of great relevance in the nutrition and production of this animal species.

Much effort has been put forward to improve the methods of research applied to the investigation of the nutritional value of the feed, involving mainly direct and indirect methods to evaluate digestibility in various species. A significant number of studies have employed the total collection of feces and urine as the reference methodology. However, this method, which is highly fastidious, has several limitations inherent to this process. The use of markers is thus an alternative to the abovementioned methods, considering that they allow for the calculation of the digestibility of nutrients. This process is performed by analyzing the nutrient concentrations in the feed and the feces produced by this feed using fewer samples without the need for total collection.

Chromic oxide $\left(\mathrm{Cr}_{2} \mathrm{O}_{3}\right)$ is one of the markers used to evaluate the feed digestibility in non-ruminant animals. This chemical compound is a metal oxide insoluble in water, alcohol and acetone and slightly soluble in acid and alkaline media. The adoption of methodologies for chromium analysis is not a 
trivial task, though, mainly in some laboratories. Furthermore, the incomplete recovery of this marker in the feces has significantly influenced the precision of results obtained with this method (RIBEIRO FILHO et al., 2008).

The present study was conducted to evaluate the effect of different inclusion levels of glycerin obtained from soybean oil on the digestibility of nutritional fractions and energy from the diet fed to pigs as determined by the total-collection and digestibility-marker methods.

\section{Material and Methods}

The experiment was conducted in Sinop - MT, Brazil, at the Federal University of Mato Grosso (UFMT), complying with the ethical principles adopted by the National Council for the Control of Animal Experimentation, after being approved by the Committee of Ethics in the Use of Animals of UFMT, under no. 23108.700673/14-4. Eight genetically homogeneous crossbred barrows were used. The pigs originated from industrial crossing and entered the experiment at an average initial weight of $24.17 \pm 0.73 \mathrm{~kg}$. The animals were distributed individually into metabolic cages, similarly to the description of Pekas (1968), in a completely randomized block design. There were four treatments and three experimental periods with two replicates per period, totaling six replicates. Each animal was considered an experimental unit.

Body weight and period were considered in the formation of the blocks. Each experimental period lasted ten days, the first five being for the adaptation to metabolic cages and diets and the last five for collection of feces and urine.

Treatments were composed of a control diet based on corn and soybean meal (Table 1), formulated following the recommendations of Rostagno et al. (2011), a diet including glycerin derived from soybean oil production (Table 2), in an isometric substitution of 5,10 and $15 \%$ of the control diet, following the methodology described by Sakomura and Rostagno (2007). To obtain the chemical composition of the diets and feces, analyses of dry matter $(\mathrm{DM})$, crude protein $(\mathrm{CP})$, mineral matter (MM), ether extract (EE), neutral detergent fiber (NDF) and gross energy (GE) were performed, following Silva and Queiróz (2002) (Table 3).

Table 1. Composition and calculated nutritional values of reference diet (as-fed basis).

\begin{tabular}{lc}
\hline Ingredient (\%) & Reference diet \\
\hline Corn & 60.48 \\
Soybean meal & 30.26 \\
Rice bran & 3.00 \\
Soy oil & 1.89 \\
Calcitic limestone & 0.52 \\
Dicalcium phosphate & 1.75 \\
Vitamin-mineral mix ${ }^{1}$ & 1.00 \\
Common salt & 0.46 \\
L-lysine & 0.15 \\
Chromium oxide & 0.50 \\
Total & 100 \\
\hline Calculated nutrient content, $\%$ & \\
\hline Metabolizable energy, $\mathrm{kcal} \mathrm{kg}^{-1}$ & 3,230
\end{tabular}


Continuation...

Crude protein

Calcium

0.72

Available phosphorus

0.36

Sodium

0.20

Digestible lysine

1.01

${ }^{1}$ Composition of the supplement per kg of diet: vitamin A(13750 UI), vitamin B1(2 mg), vitamin B2(1,25 mg), vitamin B6 (4 mg), vitamin B12 (4.5mcg), vitamin D3 (3000 UI), vitamin E (75 UI), vitamin K3 (6.25 mg), Nicotinic acid (50 mg), Pantothenic acid (30 mg), Folic acid (0.625 mg), Cobalt (1.25 mg), Copper (25 mg), Iron (150 mg), Zinc (200 mg), Manganese (75 mg), Selenium (0.7 mg), Iodine (2 mg), Coline (250 mg), Biotin (25mcg).

In the adaptation period, the feed was supplied ad libitum, and orts were determined to later calculate the feed intake based on the metabolic weight $\left(\mathrm{LW}^{0.75}\right)$. To prevent losses and facilitate ingestion, the feed was weighed and moistened with water at the ratio of $1: 1$ and supplied twice daily (7h30 and 17h30). Two feed-digestibility evaluation methodologies were analyzed: total feces and urine collection and digestibility marker. Chromic oxide $\left(\mathrm{Cr}_{2} \mathrm{O}_{3}, 0.5 \%\right)$ was used as the digestibility marker in the second methodology.

Table 2. Chemical composition of the glycerin of vegetal origin.

\begin{tabular}{lc}
\hline Items & Content \\
\hline Water (\%) & 0.49 \\
Glycerol (\%) & 86.5 \\
Methanol content (\%) & 0.05 \\
Total fatty acid (\%) & 0.30 \\
Crude energy (kcal/kg) & 5397 \\
\hline
\end{tabular}

Source: Technical report provided by the company Bunge Alimentos.

Table 3. Chemical composition of diets ( $\%$ in the dry matter).

\begin{tabular}{lcccc}
\hline & \multicolumn{4}{c}{ Glycerin levels (\%) } \\
\cline { 2 - 5 } Items & 0 & 5 & 10 & 15 \\
\hline Dry matter & 89.99 & 89.16 & 88.00 & 88.52 \\
Organic matter & 89.76 & 89.84 & 91.07 & 91.01 \\
Crude protein & 20.97 & 19.48 & 19.18 & 17.86 \\
Ethereal Extract & 4.09 & 4.07 & 3.82 & 3.72 \\
Mineral matter & 10.24 & 10.16 & 9.69 & 8.99 \\
Neutral detergent fiber & 14.74 & 13.94 & 13.79 & 13.00 \\
\hline
\end{tabular}

Feces and urine were collected once daily, in homogenized. Subsequently, samples corresponding the morning. Feces were collected, weighed and $20 \%$ of the total material were collected. This 
fraction was packed in plastic bags, identified and stored $\left(-10^{\circ} \mathrm{C}\right)$ until the end of the collection period. Urine was filtered as it was excreted through a filter tissue and passed through a funnel into the urine collection box; thereafter, it was transferred to a plastic bucket containing $10 \mathrm{~mL}$ hydrochloric acid $(\mathrm{HCl}, 1: 1)$. The total urine volume of each animal was determined in a 5-mL-graduated beaker. Samples of $20 \%$ were packed in plastic bags with lid and stored in a freezer $\left(-18^{\circ} \mathrm{C}\right)$.

At the end of the collection period, samples of feces were thawed, weighed, homogenized and dried in a forced-air oven at $60{ }^{\circ} \mathrm{C}$ for $72 \mathrm{~h}$ for pre-drying and later analyses. The organic matter (OM) level was determined as the difference between the dry matter (DM) and mineral matter (MM) values. The chromium quantities in the feces were determined by atomic absorption spectroscopy (WILLIANS et al., 1962). Urine samples were thawed and homogenized for total nitrogen and energy.

We determined the digestible fractions (DF) of DM, OM, CP, MM, EE, NDF; digestible energy (DE); metabolizable energy (ME); DE and ME corrected for the nitrogen balance (DEn and MEn); the digestibility coefficients (DC); and the metabolizability coefficients (MC), using the total feces and urine collection method and the marker method, according to Sakomura and Rostagno (2007):

$\mathrm{DF}=(\mathrm{F}$ ingested $-\mathrm{F}$ excreted in the feces $) /$ dry matter ingested;

$\mathrm{DE}=(\mathrm{GE}$ ingested $-\mathrm{GE}$ excreted in the feces $) /$ dry matter ingested;

$\mathrm{ME}=(\mathrm{GE}$ ingested $-\mathrm{GE}$ excreted in the feces GE excreted in the urine)/dry matter ingested;

DEn $=($ GE ingested - GE excreted in the feces \pm $5.45 \mathrm{NB}$ )/dry matter ingested;

MEn $=(G E$ ingested $-\mathrm{GE}$ excreted in the feces - GE excreted in the urine $\pm 5.45 \mathrm{NB}$ )/dry matter ingested;
$\mathrm{DC}$ of energy $=(\mathrm{DE} / \mathrm{GE}) \times 100$;

$\mathrm{ME}$ of energy $=(\mathrm{ME} / \mathrm{GE}) \times 100$;

$\mathrm{DF}=\mathrm{F}$ ingested $-(\mathrm{F}$ excreted in the feces $\times \mathrm{IF})$;

$\mathrm{DE}$ of diet $=\mathrm{GE}$ diet - (GE excreted in the feces $\times$ IF);

ME of diet $=$ GE diet $-((G E$ excreted in the feces + GE excreted in the urine) $\times$ IF);

$\mathrm{DEn}=\mathrm{GE}$ ingested $-(\mathrm{GE}$ excreted in the feces $\pm 5.45 \mathrm{NB} \times \mathrm{IF})$;

MEn $=$ GE ingested $-($ GE excreted in the feces + GE excreted in the urine $\pm 5.45 \mathrm{NB} \times \mathrm{IF})$; and

DC $(\%)=100-\left[100\left(\%\right.\right.$ of $\mathrm{Cr}_{2} \mathrm{O}_{3}$ in the diet $/ \%$ of $\mathrm{Cr}_{2} \mathrm{O}_{3}$ in the feces) (GE in the feces/GE in the diet)],

where:

F: nutritional fraction (DM, OM, CP, MM, EE, and NDF) or energy from the diet; NB: nitrogen balance $=$ consumed nitrogen - excreted nitrogen; IF: indigestibility factor $=$ marker concentration in the feed/marker concentration in the feces.

The experiment was conducted as a completely randomized block design in a split-plot arrangement. Analysis of variance was performed according to the following statistical model:

Yijk $=\mu+G i+P j+M k+G i \times M k+\varepsilon i j+\varepsilon i j k$,

where Yijk = observation related to the effect of glycerin level i in period $\mathrm{j}$, using digestibility method $\mathrm{k} ; \mu=$ overall mean; $\mathrm{Gi}=$ effect of glycerin inclusion level $(\mathrm{i}=0,5,10$ or $15 \%) ; \mathrm{Pj}=$ experimental period $(\mathrm{j}=1,2$ or 3$) ; \mathrm{Mk}=$ effect of digestibility evaluation method $(\mathrm{k}=$ total or marker collection); $\mathrm{Gi} \times \mathrm{Mk}=$ effect of interaction between the glycerin level $\mathrm{i}$ and digestibility evaluation method $\mathrm{k} ; \varepsilon \mathrm{ij}=$ random error associated with the plot; and eijk = random error associated with the sub-plot.

The effects related to the glycerin level were evaluated by decomposing the squares of treatments into orthogonal contrasts to determine the linear and quadratic effects. The $\mathrm{F}$ test was applied for the evaluation of the collection method. 
Both evaluations were undertaken considering a probability level of 0.05 for type-I error. The data were subjected to the Mixed procedure of Statistical Analysis System v. 6.0 (SAS Institute, Inc., Cary, NC, USA), considering a 5\% probability level. The data were subjected to ANOVA, considering the effects of feed digestibility evaluation methods, glycerin inclusion levels, and the interaction between these parameters.

\section{Results and Discussion}

There was no interaction effect between glycerin inclusion levels and the methods tested for the evaluation of digestibility of DM, OM, CP, EE, NDF (Table 4), there was an interaction effect for digestible MM (Table 5) and there was no interaction effect for energy values of the diets (Table 6).

Digestible DM, EE and NDF did not differ ( $p$ $>0.005)$ with the increase in glycerin inclusion levels (Table 4). Digestible OM values increased linearly with the glycerin inclusion in the diets. The equation generated to predict values indicated that an additional $1 \%$ glycerin in the diet would result in a digestible OM difference of 0.2165 (as-fed basis).

Increasing the glycerin inclusion might simultaneously elevate the glycerol values, since the largest part of glycerin, which is a digestible fraction of the diets, results in higher levels of digestible OM. However, the EE values were not altered by the glycerin used in the present study, which is semi-purified, because of its high glycerol and low lipid contents (Table 2). An increase in OM digestibility was also observed by Madrid et al. (2013), who used up to 5\% glycerin to growing pigs. The improvement in the digestibility of this dietary fraction demonstrates the potential use of glycerin, mainly because these authors worked with animals in the piglet stage, when their gastrointestinal tract is yet not fully developed.

Table 4. Values of digestible dry matter (DM), organic matter (OM), crude protein (CP), ethereal extract (EE), mineral matter (MM) and neutral detergent fiber (NDF) of diets to pig fed with different glycerin levels, determined with the total collection (TC) and indicator (Cr) methodologies (method).

\begin{tabular}{|c|c|c|c|c|c|c|c|c|c|c|c|}
\hline \multirow{2}{*}{$\begin{array}{l}\text { Digestible } \\
\text { fractions (\%) }\end{array}$} & \multicolumn{4}{|c|}{ Glycerin levels (\%) } & \multicolumn{2}{|c|}{ Method } & \multicolumn{4}{|c|}{ Significance* } & \multirow{2}{*}{$\begin{array}{l}\mathrm{CV} \\
(\%)\end{array}$} \\
\hline & 0 & 5 & 10 & 15 & $\mathrm{TC}$ & $\mathrm{Cr}$ & $\mathrm{MxG}^{1}$ & $\mathrm{~L}$ & $\mathrm{Q}$ & Method & \\
\hline $\mathrm{DM}$ & 77.31 & 76.84 & 76.76 & 78.69 & 77.70 & 77.10 & 0.2281 & 0.9287 & 0.0638 & 0.0843 & 1.49 \\
\hline $\mathrm{OM}$ & 78.39 & 78.77 & 80.40 & 82.12 & 80.09 & 79.75 & 0.1829 & 0.0061 & 0.2450 & 0.2535 & 1.28 \\
\hline $\mathrm{CP}$ & 17.68 & 16.47 & 16.13 & 15.33 & 16.48 & 16.33 & 0.2437 & 0.0007 & 0.3666 & 0.0951 & 1.82 \\
\hline $\mathrm{EE}$ & 2.92 & 2.89 & 2.76 & 2.73 & 2.86 & 2.80 & 0.4124 & 0.2491 & 0.9831 & 0.1143 & 8.55 \\
\hline MM & 8.29 & 8.18 & 7.74 & 7.26 & 8.57 & 7.17 & 0.0092 & 0.0021 & 0.1656 & $<0.0001$ & 4.93 \\
\hline $\mathrm{NDF}$ & 8.97 & 8.59 & 8.90 & 8.08 & 8.77 & 8.50 & 0.5952 & 0.5271 & 0.4063 & 0.2647 & 9.47 \\
\hline
\end{tabular}

*Level of significance $<0.05$. L (Linear effect) Q (Quadratic effect). ${ }^{1}$ Interaction between digestibility methodology and glycerin levels. $\left(\hat{\mathrm{Y}}_{\text {OMdig }}=78.4263+0.2165 \mathrm{X}\left(\mathrm{R}^{2}=0.3865\right) ;\left(\hat{\mathrm{Y}}_{\mathrm{CPdig}}=17.4154-0.1519 \mathrm{X}\left(\mathrm{R}^{2}=0.5950\right)\right.\right.$.

The digestible crude protein (CP) values of the diets had an inversely proportional relationship with glycerin inclusion (Table 4). The equation generated to predict values revealed that every $1 \%$ of glycerin addition to the diet would lead to a digestible $\mathrm{CP}$ difference of 0.1519 (as-fed basis). The differences in digestible $\mathrm{CP}$ values in relation to the glycerin levels can be explained by the chemical composition of the diets (Table 3), which indicates that replacing part of the control diet by glycerin reduces the 
dietary protein fractions. This can be regarded as normal, since glycerin is an energy ingredient.

Thus, glycerin inclusion did not improve the digestible fraction of CP. According to Madrid et al. (2013), glycerin does not affect the ingestion, retention, or excretion of nitrogen. Additionally, Verussa et al. (2017) observed that the performance and serum levels of urea were not affected by inclusion of up to $15 \%$ glycerin in the diets of growing pigs. In this sense, Oliveira et al. (2014) reported that the apparent ileal digestibility of nutrients (DM and CP) was not affected by glycerin inclusion, considering an ileal digestibility of glycerol greater than $99 \%$. Results obtained by Groesbeck et al. (2008), by contrast, denote that the digested nitrogen percentage showed a downward trend in pigs fed diets including glycerin in comparison with those fed soybean oil.

There was a difference $(p<0.05)$ between the digestibility-assessment methods for digestible MM, with the chromic oxide marker method showing lower values (Table 4). An interaction effect was observed between glycerin levels and collection methods for digestible mineral matter (Table 5). The digestible MM value decreased linearly when determined by the total collection method, indicating that every $1 \%$ additional glycerin in the diet would provide a digestible MM difference of 0.12 (as-fed basis). By the marker method, in turn, a quadratic response was observed, with every additional $10.09 \%$ glycerin leading to a $6.45 \%$ decrease in digestible MM (as-fed basis).

Table 5. Unfolding of interactions between glycerin levels and digestibility evaluation methods upon digestible mineral matter (MMdig).

\begin{tabular}{ccccccc}
\hline \multirow{2}{*}{ Method } & \multicolumn{4}{c}{ Glycerin levels (\%) } & \multicolumn{2}{c}{ Significance* } \\
\cline { 2 - 7 } & 0 & 5 & 10 & 15 & Linear & Quadratic \\
\hline TC & 9.11 & 9.05 & 7.57 & 7.60 & $<0.0001$ & 0.7933 \\
Cr & 7.49 & 7.36 & 5.91 & 6.82 & $<0.0001$ & 0.0038 \\
\hline
\end{tabular}

*Level of significance $<0.05$. L (Linear effect) Q (Quadratic effect)

$\hat{\mathrm{Y}}_{\mathrm{MMdigCT}}=9.2350-0.1200 \mathrm{X}\left(\mathrm{R}^{2}=0.5373\right) ; \hat{\mathrm{Y}}_{\mathrm{MMdigCr}}=7.6789-0.2263 \mathrm{X}+0.0104 \mathrm{X}^{2}\left(\mathrm{R}^{2}=0.4727\right)$.

In the present study, the underestimated digestible MM values obtained by the chromic oxide method can be explained by the possible interference of chromium with the absorption of some minerals. This occasional interference of chromic oxide as a digestibility marker may be related to the fact that the chemical compound is partially inert in the gastrointestinal tract (GIT) and can affect the absorption of minerals such as calcium and phosphorus (FERNANDEZ et al., 1999). Furthermore, chromic oxide cannot be fully recovered in the feces (SAKOMURA; ROSTAGNO, 2007) because of its high density relative to the GIT content (RIBEIRO FILHO et al., 2008).
In general, the use of chromic oxide as a marker to evaluate the feed digestibility has shown to be equivalent to the total collection method. In the present study, similarly to the observations of Lôbo Junior et al. (2001), the use of chromic oxide provided greater precision when compared with other markers such as acid detergent lignin and acid detergent insoluble ash (GOBESSO et al., 2011).

Similarly to the present study, Nunes (2012) found that the digestibility coefficients obtained with the chromic oxide marker method differed from those obtained with titanium dioxide, purified lignin, and the total collection method, underestimating the digestibility of diets for growing pigs. Morata et 
al. (2006), however, observed that the digestibility coefficients and metabolizable energy of the feed as determined by the total collection technique were frequently higher than that that determined by the chromic oxide procedure. Sakomura and Rostagno (2007) stated that the main limitation of the total collection method is the control upon the collection of feces and urine samples to collect them without contaminations like skin flakes, hair and feed, which may interfere with the determination of the feed energy. On the other hand, the marker use does not require quantification of intake and feces. In fact, a partial collection of the sample can be performed at clean sites to prevent possible contaminations. Nevertheless, the use of this method requires uniform mixture with the feed and standardization for the chemical analyses, which could originate significant variability of results.

An increasing linear effect was observed on the DC of energy, DE, DEn, MC of energy, ME and MEn of the diets as function of glycerin inclusion, but these were not influenced by the collection methods (Table 6). The equations generated to predict values showed that every additional $1 \%$ glycerin in the diet would generate an 8.37 and 7.45 $\mathrm{kcal} \mathrm{kcal}^{-1}$ difference in DE and ME (as-fed basis), respectively; this would mean a 126 and 112 kcal increase in the diets containing $15 \%$ glycerin. These results reinforce the expressive energy potential of glycerin in pig diets and that it can be characterized as an energy feedstuff alternative to conventional ingredients, as reported by Gomide et al (2012).

Table 6. Digestibility coefficient of energy (DCenergy), digestible energy (DE), digestible energy corrected by nitrogen balance (DEn), metabolizable coefficient of the energy (MCenergy), metabolizable energy (ME), metabolizable energy corrected by nitrogen balance (MEn), of diets to pigs fed with different glycerin levels, determined with the total collection (TC) and indicator (Cr) methodologies (method).

\begin{tabular}{|c|c|c|c|c|c|c|c|c|c|c|c|}
\hline & \multicolumn{4}{|c|}{ Glycerin levels (\%) } & \multicolumn{2}{|c|}{ Method } & \multicolumn{4}{|c|}{ Significance* } & \multirow{2}{*}{$\begin{array}{l}\mathrm{CV} \\
(\%)\end{array}$} \\
\hline & 0 & 5 & 10 & 15 & $\mathrm{CT}$ & $\mathrm{Cr}$ & $\mathrm{MxG}^{1}$ & $\mathrm{~L}$ & Q & Method & \\
\hline DC energy (\%) & 85.66 & 86.14 & 87.21 & 88.76 & 87.28 & 86.61 & 0.2228 & 0.0307 & 0.4066 & 0.0839 & 4.73 \\
\hline $\mathrm{DE}(\mathrm{kcal} / \mathrm{kg})$ & 3377 & 3435 & 3471 & 3543 & 3470 & 3443 & 0.2218 & 0.0092 & 0.7747 & 0.0847 & 1.49 \\
\hline DEn $(\mathrm{kcal} / \mathrm{kg})$ & 3364 & 3423 & 3459 & 3532 & 3458 & 3431 & 0.2220 & 0.0084 & 0.7846 & 0.0848 & 1.49 \\
\hline MC energy $(\%)$ & 82.61 & 83.06 & 83.99 & 85.35 & 83.50 & 84.01 & 0.0906 & 0.0419 & 0.4644 & 0.3519 & 2.22 \\
\hline $\mathrm{ME}(\mathrm{kcal} / \mathrm{kg})$ & 3257 & 3312 & 3343 & 3407 & 3320 & 3340 & 0.0895 & 0.0123 & 0.8549 & 0.3488 & 2.22 \\
\hline MEn (kcal/kg) & 3245 & 3301 & 3332 & 3397 & 3310 & 3328 & 0.0898 & 0.0114 & 0.8665 & 0.4143 & 2.22 \\
\hline
\end{tabular}

*Level of significance $<0.05$. L (Linear effect) Q (Quadratic effect).

${ }^{1}$ Interaction between digestibility methodology and glycerin levels.

$\left(\hat{\mathrm{Y}}_{\mathrm{DCenergy}}=85.8683+0.1498 \mathrm{X}\left(\mathrm{R}^{2}=0.1669\right) ; \hat{\mathrm{Y}}_{\mathrm{DE}}=3395.8892+8.3749 \mathrm{X}\left(\mathrm{R}^{2}=0.2866\right) ;\right.$

$\hat{\mathrm{Y}}_{\mathrm{DEn}}^{\mathrm{DCenergy}}=3303.9100+9.4756 \mathrm{X}\left(\mathrm{R}^{2}=0.3176\right) ; \hat{\mathrm{Y}}_{\mathrm{MCenergy}}^{\mathrm{DE}}=84.1434+0.1279 \mathrm{X}\left(\mathrm{R}^{2}=0.0755\right) ;$

$\hat{\mathrm{Y}}_{\mathrm{ME}}^{\mathrm{DEn}}=3327.6810+7.4540 \mathrm{X}\left(\mathrm{R}^{2}=0.1492\right) ; \hat{\mathrm{Y}}_{\mathrm{MEn}}^{\mathrm{M}}=3255.2585+8.5487 \mathrm{X}\left(\mathrm{R}^{2}=0.2768\right)$.

The increase in the DE, DEn, ME and MEn values of the diets is directly related to higher dietary glycerin levels $(3,405$ and $3,370 \mathrm{kcal} / \mathrm{kg} \mathrm{DE}$ and 3,280 and 3,261 kcal/kg ME as determined by the methods of total collection and chromic oxide marker, respectively) as compared with control diet (Tables 1 and 6). Therefore, increasing the glycerin inclusion levels led to higher dietary energy values. In this sense, the DC and MC of the energy from the diets increased because the glycerin has higher coefficients than control diet. Higher amounts of dietary metabolizable and digestible energy with glycerin inclusion in the basal diet were also reported by Silveira et al. (2015), who evaluated a 
product with $75 \%$ glycerol and $14 \%$ fatty acids.

The increase in dietary energy values obtained by glycerin inclusion may be a strategy for pigs, especially for those categories with difficulties of consumption such as piglets, because of their state of adaptation to new diets, and lactating sows when they have increased demands caused by a high metabolic rate. The stimulus to intake in diets containing glycerin may also originate from its characterization; Groesbeck et al. (2008) submitted that crude glycerin has a sweetish taste, which improves the palatability and consequently the consumption of feed. The increase in energy value with glycerin inclusion may also be positive for pigs in heat-stress situations, as they naturally tend to reduce intake in an attempt to reduce heat production, which limits their development.

Lammers et al. (2008), however, observed a decrease in the estimate of metabolizable energy with an increase in glycerin inclusion in the diet fed to barrows in the nursery stage. In pigs, the activation of enzymes for the use of glycerol may be limited, and high dietary levels of glycerin may lead to a low energy content, because the enzymatic system of glycerol kinase becomes saturated in the conversion of glycerol to glycerol-3-phosphate, the excess glycerol being excreted in the urine (DOPPENBERG; VAN DER AAR, 2007). Anyway, the results of the present study suggest a small loss, since ME:DE ratios of the diets were close to 0.96 .

The data obtained in the present work suggest that the limit of glycerin use was not reached, since some of the parameters showed linear responses. In the study of Mendonza et al. (2010), the limit of glycerin use was reached at the level of $30 \%$, leading the excess glycerin to be excreted in the urine, reducing its metabolizability. Lin (1977) and Gallego et al. (2014) demonstrated the use of glycerin as a readily available energy source as a result of its fast absorption in the intestine and easy metabolism in the liver. Thus, depending of the nutritional state of the animal, glycerin may be available for lipid formation or energy production through glycolysis or the citric acid cycle. Eunsook et al. (2013) showed that liver has the capacity to phosphorylate free glycerol via glycerol kinase (GK) to yield glycerol 3-phosphate (G3P), which then becomes esterified with fatty acids. These authors also reported that the contribution of exogenous glycerol to the glycerol moiety of acylglycerols was important in the liver and that the free glycerol contribution was similar to glucose in fed animals but was almost two-fold greater than glucose in fasted animals. In this regard, Hagopian et al. (2008) showed that there was a metabolic adaptation so that the glycerol could be used at a higher ratio as an energy source through an increase in the activities of GK and glycerol-3phosphate dehydrogenase in the liver, when the diet of rats was formulated with caloric restriction.

In any case, limitations in the use of glycerin as an ingredient in pig diets are related to quality factors inherent to the very glycerin production. In fact, glycerin production requires special attention because of concerns regarding the residual levels of sodium, potassium, methanol, moisture, among others, before it is used in animal feeding (MAPA, 2010). These factors can markedly influence the viable levels of glycerin inclusion in diets.

\section{Conclusions}

Inclusion of up to $15 \%$ glycerin derived from soybean oil production increase the digestibility of organic matter, the digestible energy and the metabolizable energy of the pig diets.

The chromic oxide marker and total collection methods are equivalent in the determination of the digestible fractions of dry matter, organic matter, ether extract, neutral detergent fiber and energy of the pig diets.

\section{Acknowledgments}

The authors thank Fundação de Amparo à 
Pesquisa do Estado de Mato Grosso (FAPEMAT) for the financial support for the research and the fellowship granted to the first author; and Bunge Alimentos for donating the glycerin.

\section{References}

AGÊNCIA NACIONAL DO PETRÓLEO, GAS NATURAL E BIOCOMBUSTIVEIS - ANP. Dados estatísticos. Produção de biodiesel. Brasília: BRASIL, Governo Federal, jan. 2017. Disponível em: <http:// www.anp.gov.br/wwwanp/dados-estatisticos>. Acesso em: 17 jan. 2017.

DOPPENBERG, J.; VAN DER AAR, P. J. Biofuels: implications for the feed industry. Wageningen: Wageningen Academic Publishers, 2007. 117 p.

DROSGHIC, L. C. A. B.; PEREIRA, T. L.; CORASSA, A. Inclusão de glicerol e glicerina em dietas para suínos determinados no Brasil: revisão. Scientific Eletronic Archives, Sinop, v. 2. n. 1, p. 46-49, 2013.

EUNSOOK, S. J.; SHERRY, A. D.; MALLOY, C. R. Metabolism of glycerol, glucose, and lactate in the citric acid cycle prior to incorporation into hepatic acylglycerols. Journal of Biological Chemistry, Rockville, v. 288, n. 20, p. 14488-14496, 2013.

FERNANDEZ, F.; MIQUEL, A. G.; MARTINEZ, R.; SERRA, E.; GUINEA, J.; NARBAIZA, F. J.; CASERAS, A.; BAANANTE, I. V. Dietary chromic oxide does not affect the utilization of organic compounds but can alter the utilization of mineral salts in gilthead sea bream Sparus aurata. Journal of Nutrition, Bethesda, v. 129, n. 5, p. 1053-1059, 1999.

GAllego, A. G.; MOREIRA, I.; POZZA, P. C.; CARVALHO, P. L. O.; SIERRA, L. M. P.; COSTA FILHO, C. L. Neutral semi-purified glycerin in starting pigs feeding. Semina: Ciências Agrárias, Londrina, v. 35, n. 5, p. 2831-2842, 2014.

GOBESSO, A. A. O.; RAMOS, S. C.; CASALECH, F. L.; MOREIRA, A. M. F. O.; BRANDI, R. A.; RENNÓ, F. P.; FREITAS JUNIOR, J. E. Indicadores para estimativa da digestibilidade aparente total em equinos. Revista Brasileira de Saúde e Produção Animal, Salvador, v. 12, n. 1, p. 264-274, 2011.

GOMIDE, A. P. C.; BRUSTOLINI, P. C.; FERREIRA, A. S.; PAULINO, P. V. R.; LIMA, A. L.; SCOTTÁ, B. A.; RODRIGUES, V. V.; CAMARA, L. R. A.; MOITA, A. M. S.; OLIVEIRA JUNIOR, G. M.; FERREIRA, R. C.; FORMIGONI, A. S. Substituição de milho por glicerina bruta em dietas para suínos em terminação. Arquivo
Brasileiro de Medicina Veterinária e Zootecnia, Belo Horizonte, v. 64, n. 5, p. 1309-1316, 2012.

GROESBECK, C.N.; MCKINNEY,L. J.; DEROUCHEY, J. M.; TOKACH, M. D.; GOODBAND, S. S.; DRITZ, J. L.; NELSSEN, A. W.; DUTTLINGER, A. C.; FAHRENHOLZ, A.C.; BEHNKE, K. C. Effect of crude glycerol on pellet mill production and nursery pig growth performance. Journal of Animal Science, Champaign, v. 86, n. 9, p. 2228-2236, 2008.

HAGOPIAN, K.; RAMSEY, J. J.; WEINDRUCH, R. Enzymes of glycerol and glyceraldehyde metabolism in mouse liver: effects of caloric restriction and age on activities. Bioscience Reports, London, v. 28, n. 2, p. 107-115, 2008.

JAGGER, S. Pigs: use of biofuel co-products, economics and nutritional limitations. In: Proceedings of the British Society of Animal Science. British Society of Animal Science. Scarborough, 2008. p. 286-287. Available at: $\quad$ <ttp://www.bsas.org.uk/Publications/Annual_ Conference_Proceedings $>$. Accessed at: 17 jan. 2017.

LAMMERS, P. J.; KERR, B. J.; WEBER, T. E.; DOZIER, W. A.; KIDD, M. T.; BREGENDAHL, K.; HONEYMAN, M. S. Digestible and metabolizable energy of crude glycerol for growing pigs. Journal of Animal Science, Champaign, v. 86, n. 3, p. 602-608, 2008.

LEITE, R. G.; CORASSA, A.; TON, A. P. S.; KOMIYAMA, C. M.; AMORIM, A. B.; KIEFER, C. Glycerin levels while maintaining the electrolyte balance in finishing pig diets. Revista Brasileira de Zootecnia, Viçosa, MG, v. 46, n. 3, p. 211-217, 2017.

LIN, E. C. C. Glycerol utilization and its regulation in mammals. Annual Review of Biochemistry, Palo Alto, v. 46, n. 1, p. 765-795, 1977.

LÔBO JUNIOR, M. F.; REZENDE, A. S. C.; SALIBA, E. O. S.; SAMPAIO, I. B. M. Coeficientes de digestibilidade aparente pelos métodos de indicadores e coleta total de fezes em cães. Arquivos Brasileiro de Medicina Veterinária e Zootecnia, Belo Horizonte, v. 53, n. 6, p. 691-694, 2001.

MADRID, J.; VILLODRE, C.; VALERA, L.; ORENGO, J.; MARTINEZ, S.; LÓPEZ, M. J.; MEGIAS, M. D.; HERNANDEZ, F. Effect of crude glycerin on feed manufacturing, growth performance, plasma metabolites, and nutrient digestibility of growing-finishing pigs. Journal of Animal Science, Champaign, v. 91, n. 8, p. 3788-3795, 2013.

MENDONZA, O. F.; ELLIS, M.; McKEITH, F. K.; GAINES, A. M. Metabolizable energy content of refined glycerin and its effects on growth performance, and 
carcass and pork quality characteristics of finishing pigs. Journal of Animal Science, Champaign, v. 88, n. 12, p. 3887-3895, 2010.

MINISTÉRIO DA AGRICULTURA, PECUÁRIA E ABASTECIMENTO - MAPA. Ministério da agricultura autoriza novo uso da glicerina. Brasília: BRASIL, Governo Federal, 2010. Disponível em: <http://www. sindiracoes.org.br/index.php?option $=$ com_content\&task =view\&id=972Itemid=1>. Acesso em: 11 fev. 2014 .

MORATA, R. L.; MACHADO, T. M. M.; ALBINO, L. F. T.; ROSTAGNO, H. S.; DETMANN, E.; FERNANDES, L. T. O.; PARENTE, H. N.; ANTUNES, K. V.; ALMEIDA, A. C.; CSEMARK JUNIOR, A. C. Técnicas de avaliação dos valores energéticos e dos coeficientes de digestibilidade de alguns alimentos para emas (Rhea americana) em crescimento. Revista Brasileira de Zootecnia, Viçosa, MG, v. 35, n. 4, p. 1381-1388, 2006.

NUNES, A. N. Validação de técnicas instrumentais para quantificação de amido e de indicadores de digestibilidade para dietas de suínos em crescimento. 2012. Dissertação (Mestrado em Zootecnia) - Universidade Federal de Minas Gerais, Belo Horizonte.

OLIVEIRA, J. S.; ANTONIASSI, R.; FREITAS, S. C.; MULLER, M. D. Composição química da glicerina produzida por usinas de biodiesel no Brasil e potencial de uso na alimentação animal. Ciência Rural, Santa Maria, v. 43, n. 3, p. 509-512, 2013.

OLIVEIRA, L.; MADRID, J.; RAMIS, G.; MARTÍNEZ, S.; ORENGO, J.; VILLODRE, C.; VALERA, L.; LÓPEZ, M. J.; PALLARÉS, F. P.; QUEREDA, J. J.; MENDONÇA, L.; HERNÁNDEZ, F. Adding crude glycerin to nursery pig diet: effect on nutrient digestibility, metabolic status, intestinal morphology and intestinal cytokine expression. Livestock Science, Atlanta, v. 167, p. 227-235, 2014.
PEKAS, J. C. Versatile swine laboratory apparatus for physiologic and metabolic studies. Journal of Animal Science, Champaign, v. 27, n. 5, p. 1303-1309, 1968.

RIBEIRO FILHO, H. M. N.; ZIMERMANN, F. C.; KOZLOSKI, G. V. Baixa dosagem de óxido de cromo para estimativa da produção fecal em bovinos. Ciência Rural, Santa Maria, v. 38, n. 9, p. 2567-2573, 2008.

ROSTAGNO, H. S.; ALBINO, L. F. T.; DONZELE, J. L.; GOMES, P. C.; OLIVEIRA, R. F.; LOPES, D. C.; FERREIRA, A. S.; BARRETO, S. L. T.; EUCLIDES, R. F. Tabelas brasileiras para aves e suínos: composição de alimentos e exigências nutricionais. 2. ed. Viçosa, MG: Universidade Federal de Viçosa, 2011. 252 p.

SAKOMURA, N. K.; ROSTAGNO, H. S. Métodos de pesquisa em nutrição de monogástricos. Jaboticabal: FUNEP, 2007. 283 p.

SILVA, D. J.; QUEIROZ, A. C. Análises de alimentos: métodos químicos e biológicos. 3. ed. Viçosa, MG: Editora UFV, 2002. 235 p.

SILVEIRA, H.; RODRIGUES, L. M.; AMARAL, L. G. M.; CERQUEIRA, L. G. S.; PHILOMENO, R.; CANTARELLI, V. S. Digestible and metabolizable energy of crude glycerin for finishing pigs. Acta Scientiarum. Animal Sciences. Maringá, v. 37, n. 1, p. 41-45, 2015.

VERUSSA, G. H.; CORASSA, A.; PINA, D. S.; TON, A. P. S.; KOMIYAMA, C. M.; TEIXEIRA, A. O. Performance and sérum parameters of growing pigs fed semi-purified glycerin. Revista Colombiana de Ciencias Pecuarias, Antioquia, v. 30, n. 1, p. 11-20, 2017.

WILLIANS, C. H.; DAVID, D. J.; ILSMAA, O. The determination of chromic oxide in faeces samples by atomic absorption spectrophotometry. Journal Agriculture Science, Champaign, v. 59, n. 1, p. 381-385, 1962. 
